مقاله يزوهشى

مجله دانشعاه علوم :ز شكى رفسنجان

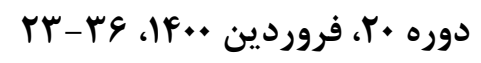

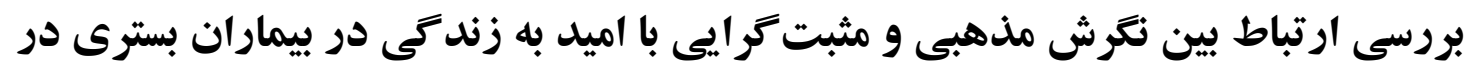

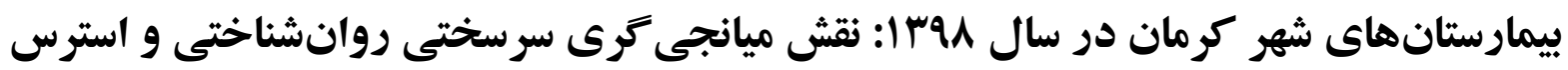
ادراكت شده: يكك مطالعه توصيفى مياتي

عليرضا حكيمى'، فرشيد خسرويور'، سعيده خجسته جترودى"

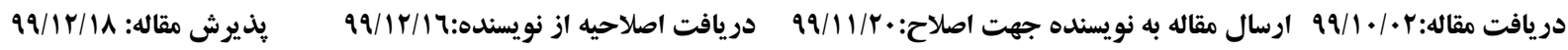

زمينه و هدف: ايمان به خدا و اميدوارى، نقش بهسزايى در ادامه روند زندكى تمامى افراد جامعه و بلويزه بيماران ايفاء مى كند. مطالعه حاضر با هدف تعيين رابطه نكرش مذهبى و مثبترايى با اميد به زندگى با توجه به نقش ميانجى سرسختى روانشناختى و استرس ادراى شده در بيماران بسترى در بيمارستانهاى شهر كرمان انجام شد. مواد و روشها: روش يزوهش، توصيفى و از نوع مدليابى معادلات ساختارى بود. جامعه يزوهش شامل تمامى بيماران

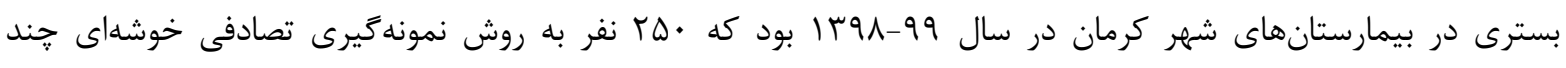

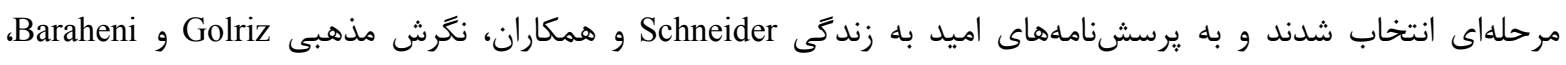

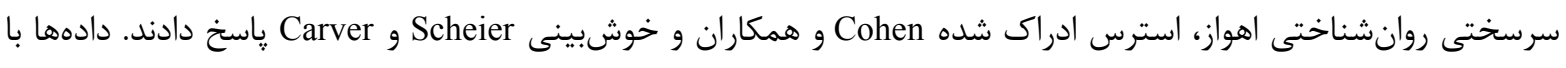

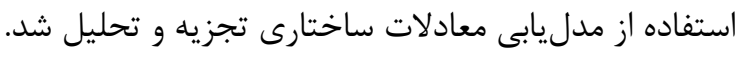

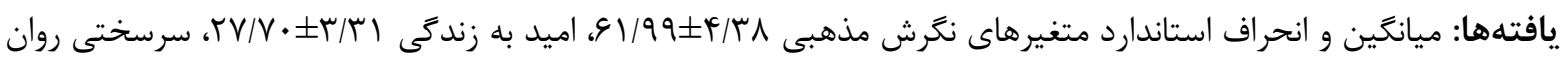

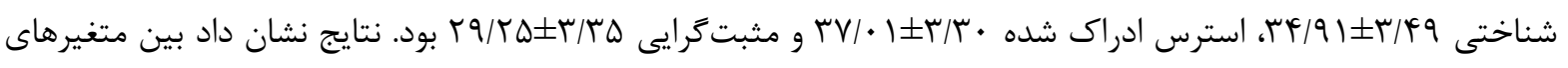

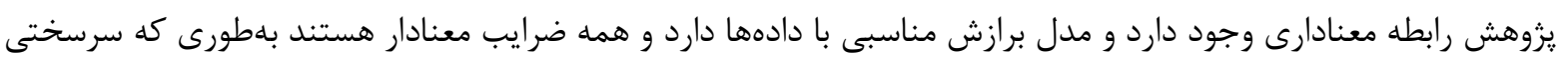

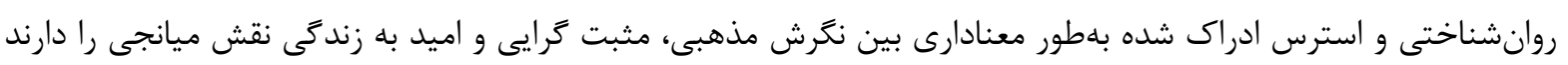
. $(\mathrm{p}<\cdot 1 \cdot \cdot 1)$

نتيجهَّيرى: نكَرش مذهبى و مثبت گرايى مى توانند هم بهطور مستقيم و هم به واسطه سرسختى روانشناختى و استرس

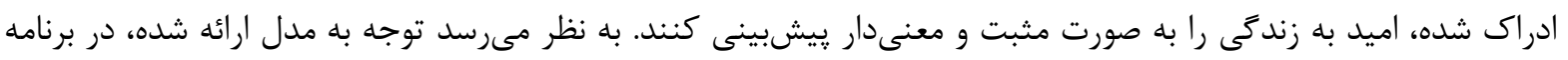
درمانى و مشاورهاى بيماران مفيد خواهد بود.

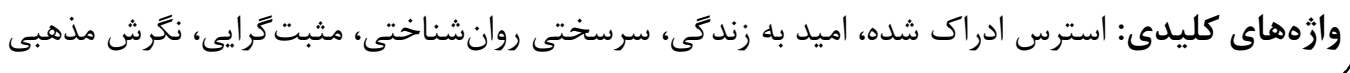

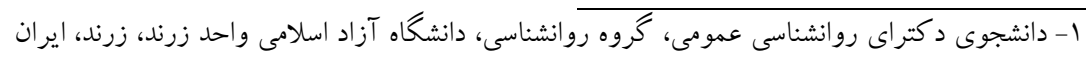

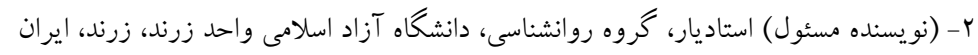

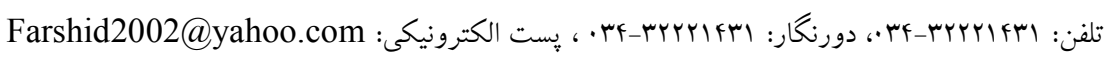

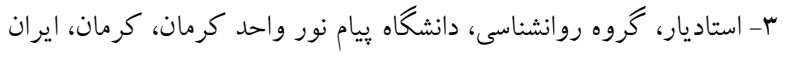


مشكلات را حل مى كنند و به جاى دورى از مشكلات آنها

مقدمه

را به عنوان فرصت يِشرفت ارزيابى مى كنند [9]. سرسختى، ظرفيتها و ويزگى هاى مثبتى است كه موجب مقابله مثبت و مفيد فرد با جالشهاى محيطى مىشود و او را از اختلالات روانى مرتبط با استرس مصون مىدارد [•l]. Fouladi و Shahidi نشان دادند كه سرسختى روانشناختى با اميد به زندگى رابطه دارد [11] [11]. اميد و استرسهاى روانشناختى در شرايط سخت بر بهزيستى روانى تأثير گذارند. استرس ادراك شده ( Perceived stress )، سيستم روانشناختى فرد را به صورت اختلال در عملكرد شناختى، افزايش نكرانى و انعطاف نايذيرى تحت تأثير قرار مىدهد [1 [1]. استرس عبارت است از تجربه كردن وقايعى كه براى آسايش جسمى يا روان فرد مخاطره آميز تلقى مىشوند [بr]]. McKay و همكاران، ارتباط بين اميد

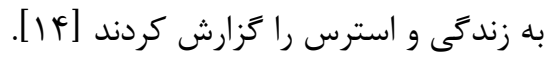
بررسى متغيرهاى نكرش مذهبى، اميد به زندگى و سرسختى روانشناختى هدف كوششهاى يزوهشى فراوانى بوده است كه به يافتههاى با ارزش منتهى

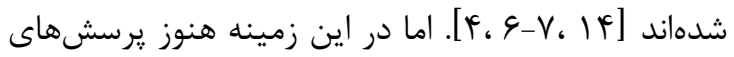
فراوانى وجود دارند كه ضرورت تدابير جديد يزوهشى و در نظر گرفتن متغيرهاى ديگر را به ميان مى آورند. بنابراين، يزوهش حاضر با هدف تعيين رابطه نكرش مذهبى و مثبتگرايى با اميد به زندگى با توجه به نقش ميانجى سرسختى روانشناختى و استرس ادراك شده در بيماران بسترى در بيمارستانهاى شهر كرمان در قالب مدل مفهومى

$$
\text { زير انجام گرفت (شكل ()). }
$$

اميد به زندگى (Life expectancy) يك شيوه تفكر شناختى هدفگرا است. اميدوارى افراد را براى رسيدن به اهداف دشوارشان متعهد مىسازد [1]. يكى از متغيرهاى مرتبط با اميد به زندگى، نكرش مذهبى Religious) Attitude) و ارائه دهنده باورها و ارزشها است كه اين ويزگىها مىتواند زندگى افراد را متأثر سازند [ب]. نتايج مطالعه و همكاران نشان داد كه بين باورهاى مذهبى و Ofstedal اميد به زندگى ارتباط وجود دارد [F]. مثبترايى (Positivism) به عنوان متغيرى مرتبط با اميد به زندكى، پديدهاى روانشناختى را در سطحهاى مختلف مدنظر قرار مىدهد. هيجانهاى مثبت ذهنيت مردم را بيشتر باز نكَه مىدارند و آنها را تشويق مىكنند تا از انديشه يا عمل، مرزهاى جديدى را به وجود بياورند. اين هيجانها، با تأثير بر روى تفكر وسعت يافته، رشد ويزگى هاى شخصيتى مثبت مانند مقاومت و انعطافيذيرى، و و خوشبينى را موجب مىشوند [ه]]. Saeidi و Birashk در يزوهش خود نشان دادند كه روان درمانى مثبت به زندگى بيماران تأثير دارد [ع]. Ali-Akbari و همكاران نيز اثربخشى روان درمانى مثبت

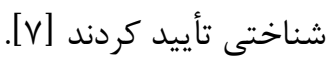
سرستى روانشناختى (Psychological hardiness) يك ويزگى شخصيتى است كه به عنوان منبع مقاومت در مقابل با رويدادهاى تنشزاى زندگى عمل مىكند [^]. افراد سرسخت قدرت كنترل بيشترى بر رويدادها داشته، بهتر 


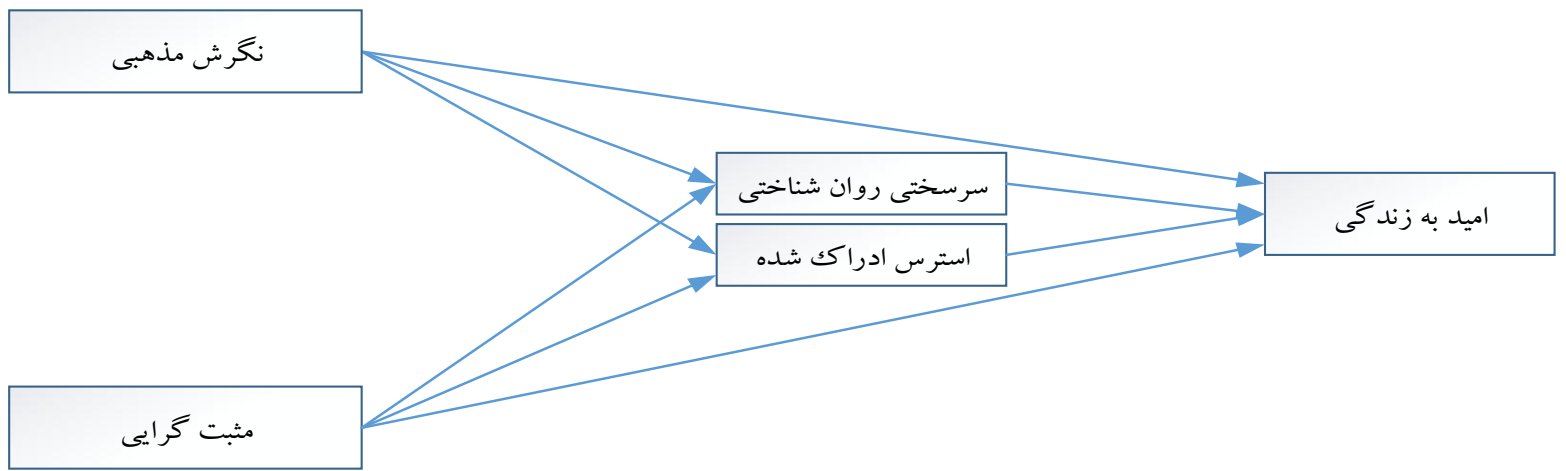

شكل ا - مدل مغهومى ارتباط بين نكرش مذهبع و مثبت كرايع با اميد به زندكى دو بيماران بسترى دو بيمارستانهاى شهر كرمان: نقش ميانجى كرى سرسختى روانشناختى و استرس ادراك شلده

ملاكهاى ورود شامل دارا بودن سلامت روانى، بسترى

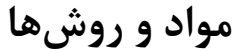

بودن در بخشهاى درمانى بيمارستانهاى شهر كرمان، داشتن حداقل ها سال سن و حداقل مدرك سيكل بود و ملاكهاى خروج هم شامل اختلالات سايكوتيك مثل اسكيزوفرنى، هذيانى (با تزارش و سؤال از بيمار)، بيمارى صرع، اختلال دوقطبى غيرقابل كنترل و عدم تمايل به شركت در يزوهش در نظر كَفته شد. اين مطالعه همجنين داراى كد اخلاق IR.ZARAND.REC.1399.011 از دانشعاه آزاد اسلامى واحد زرند مىباشد. در يزوهش حاضر از يرسشنامهاى زير استفاده شد:

- Religious ) Golriz يرسشنامه نخرش مذهبى Attitude Questionnaire

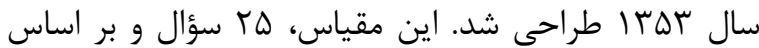
مقياس ليكرت ه درجه اى (· تا f) نمرهگذارى مىشود،

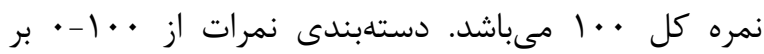
اساس جهار مقياس به ترتيب عالى، خوب، متوسط و ضعيف

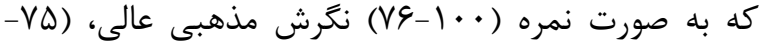
اين مطالعه توصيفى و از نوع مدليابى معادلات ساختارى بود. جامعه آمارى يزوهش حاضر را تمامى بيماران بسترى در بيمارستانهاى شهر كرمان در سال 99-91"| تشكيل دادند. حداقل حجم نمونه لازم در مدلهاى ساختارى . ب نفر است [ها]. براى انتخاب نمونه از روش نمونهَيرى تصادفى خوشهاى جند مرحلهاى استفاده شد. ابتدا به صورت تصادفى با روش قرعه كشى از بين بيمارستانهاى شهر كرمان، † بيمارستان دولتى و ץ بيمارستان خصوصى انتخاب شد. سيس به صورت در دسترس، · · بيمار بخشهاى بسترى به عنوان نمونه انتخاب شدند. ضمن اخذ مجوز از بيمارستانها و پر از توضيح اهداف يزوهش و محرمانه بودن اطلاعات به بيماران، رضايت آكاهانه بيماران جهت شركت در يزوهش جلب شد. سيس يرسشنامههاى اميد به زندگى Schneider و همكاران، نكرش مذهبى Golriz و Baraheni، سرسختى روانشناختى اهواز بر روى افراد نمونه اجرا شد. 
ع ب بررسى ارتباط بين نگرش مذهبى و مثبت گرايى با اميد به زندگى در بيماران بسترى در بيمارستان ...

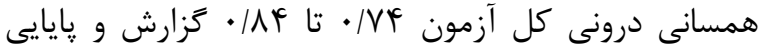

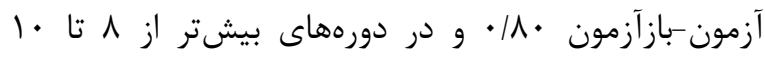
هفته، از اين ميزان نيز بالاتر بهدست آمد. همسانى درونى

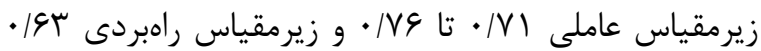

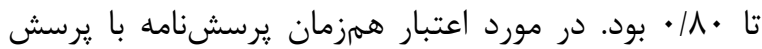
نامههاى خوشبينى، انتظار دستيابى به هدف و عزت نفس همبستكى • •// تا • ع/• دارد كه نشان دهنده اعتبار اين يرسشنامه است [19]. ميزان ضريب پايايى به روش آلفاى كرونباخ در اين يزوهش r r • به دست آمد.

- يرسشنامه سرسختى روانشناختى اهواز (ر) Psychological Hardiness Scale

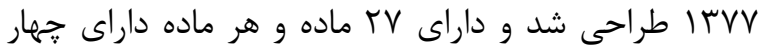
كزينه هرگز، به ندرت، گَاهى اوقات و بيشتر اوقات و نمره كذارى به ترتيب مقادير •، 1، ؟، r است. گويههاى צ، V،

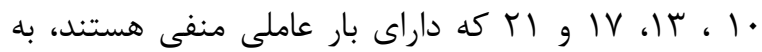
شيوه معكوس نمرهگذارى مىشوند. دامنه نمره از • تا 11 بوده و نمره بالا بيانكر سرسختى روانشناختى بالا است. ضرايب پايايى پرسشنامه با روش بازآزمايى و آلفاى كرونباخ به ترتيب AF/ • و V\&/ • كزارش شده است. روايى اين آزمون به روش روايى همزمان با سه ملاك مقياس اضطراب عمومى، يرسشنامه افسردكى و خودشكوفايى مزلو محاسبه شد و ضرايب به دست آمده به ترتيب \$Q|• ، \&V|• و r\&|• و روايى همزمان آن با تعريف سازه سرسختى روانشناختى رضايت بخش بود [•r]]. ميزان ضريب يايايى به روش آلفاى كرونباخ در اين يزوهش V^/ • به دست آمد.

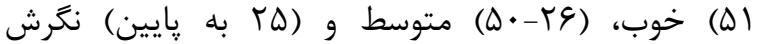
مذهبى ضعيف طبقهبندى شد. اعتبار اين آزمون از طريق ضريب همبستخى با آزمون Allport، Vernon و Lindzey برابر با •^/·• مىباشد [ع]]. در ايران، Sadeghi، براى اعتباريابى اين يرسشنامه از طريق روش گروههاى شناخته شده نيز استفاده كرد. تفاوت ميانگين بين دو گروه عادى و مذهبى معنى دار بود و ميزان تهيه شده بين دو گروه تفاوت مى گذارد. اين يرسشنامه در سالهاى اخير مورد ارزيابى مجدد قرار كرفت و پِايايى اين گرسشنامه از روش Spearman Brown به دست آمد [IV] [V] ميزان ضريب يايايى به روش آلفاى كرونباخ در اين يزوهش • V/ • به دست آمد. Life Expectancy ) Snyder يرسشنامه اميد به زندكى Questionnaire در سال 1991 تهيه شده است. اين يرسشنامه براى افراد ها سال به بالا طراحى و هدف آن ارزيابى ميزان اميد به زندگى در افراد مىباشد. يرسشنامه داراى rا سؤال و نمرهكذارى آن بر اساس طيف ليكرت ع عزينهاى از 1 (كاملاً غلط) تا \& (كاملاً درست) است. جهمار سؤال براى سنجش بـ

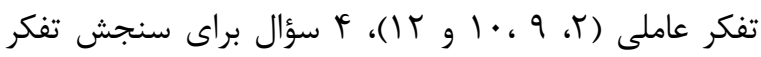

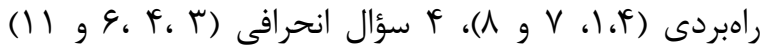
اختصاص دارد. نمره بالاتر نشان دهنده اميد بيشتر است. سازندَان مقياس اعتبار آن را از طريق بازآمايى بعد از ؟ هفته AD|• و براى زير مقياس تفكر عامل |A|• و براى راهبردها VY/ • خزارش كردند. همسانى درونى مقياس از

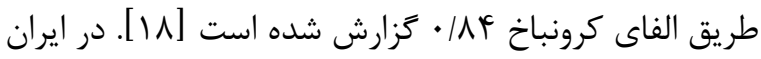


Kزارش شد [rr]]. اين يرسشنامه توسط - Khodabakhshi Koolaee بهدست آمده براساس روش بازآزمايى و آلفاى كرونباخ به ترتيب †F|• و •V/ • به دست آمد. روايى همزمان بين مقياس خوش بينى با افسردگى و خودتسلط يابى مورد تأييد قرار گرفت [rF]. ميزان ضريب پايايى به روش آلفاى كرونباخ در اين يزوهش سN/ • به دست آمد. براى تحليل دادها از نرمافزار SPSS نسخه FF به منظور محاسبه شاخصهاى آمار توصيفى از جمله ميانخين و انحراف معيار و براى تحليل مسير به وسيله نرمافزارهاى AMOS نسخه سז و Pls استفاده شد. قبل از تحليل دادهها براى اطمينان از اينكه دادهاى اين يزوهش مفروضههاى زيربنايى مدليابى معادلات ساختارى را برآورد مىكنند، קند مفروضه اصلى معادلات ساختارى شامل دادهاى كمشده (Missing) از روش جايخزينى (Replacement) استفاده شد. براى بررسى نرمال بودن متغيرها از آزمون Kolmogorov-Smirnov داد كه دادهها داراى توزيع نرمال (ه>•P> (P>) مىباشند. هم جنين همخطى جندگًانه بين متغيرها با استفاده از آماره تحمل (Tolerance) و عامل تورم واريانس ( Inflation Factor (Variance مورد بررسى قرار گرفت. نتايج نشان داد كه ارزشهاى تحمل به دست آمده براى متغيرها بالاى • |/. هستند و نشان دهنده عدم وجود همخطى جندگانه بين متغيرها است و همرجنين مقدار عامل تورم واريانس به دست آمده براى متغيرها كوجگتر از • إبودند كه نشان دهنده
- يرسشنامه استرس ادراى شده ( Perceived Stress Scale): مقياس استرس ادراك شده به وسيله Cohen و همكاران در سال ب1911 بهمنظور آكاهى از اين كه افراد تجارب دشوار و طاقتفرساى خويش را جحَونه ارزيابى مىكنند، توسعه يافت. در اين مقياس خودگزارشدهى از افراد تقاضا مىشود كه بر روى يك طيف ينج درجهاى از • (هرگز) تا F (هميشه) مشخص كنند كه اغلب در طول هفته كَشته جه احساسى داشتهاند. براى مثال، آيا در خلال •ا هفته كذشته، اغلب براى كنترل امور مههم زندكى خود احساس ناتوانى كردايد؟ مقياس مشتمل بر flf عبارت است

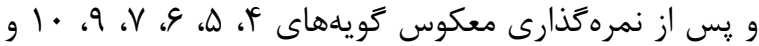
سا از تجميع نمره تمامى گويهها براى هر فرد نمره كلى بهدست مى آيد. ضرايب همسانى درونى براى هر يك از زير مقياسها و نمره كلى در محدوده \&A| • تا ع|1/ • بهدست آمد [ابr]. در مطالعه Safaei و Shokri ضرايب آلفاى كرانباخ براى عاملهاى خودكارآمدى ادراى شده و درماندگى ادراك شده و نمره كلى استرس ادراك شده به ترتيب برابر با •^/،

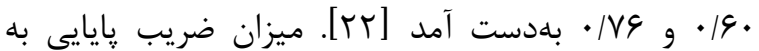
روش آلفاى كرونباخ در اين يزوهش AF| • به دست آمد. Scheier يرسشنامه مثبت كرايى: اين :رسشنامه توسط و Carver در سال 1919 ساخته شده است. يرسشنامه داراى • ا عويه است. گويههاى ז، ه، و و 1 انحرافى هستند و نمرهاى به آنها تعلق نمى گيرد و گويههاى سا، V و 9 بهصورت معكوس و براساس مقياس ينج درجهاى ليكرت نمره كذارى مىشود. ضريب آلفاى كرونباخ در نسخه اصلى يرسشنامه VY/ • بهدست آمد و روايى همگرا آن نيز مطلوب رك 
\^ بررسى ارتباط بين نكرش مذهبى و مثبت گرايى با اميد به زندگى در بيماران بسترى در بيمارستان ...

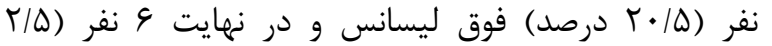

درصد) داراى مدرك دكترى درصد بودند. عب نفر (F/F

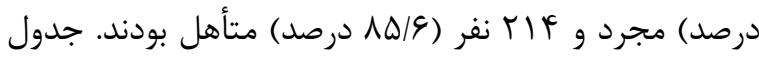
ا، ميانگين و انحراف معيار متغيرهاى نخرش مذهبى، مثبت كرايى، سرسختى روانشناختى، استرس ادراك شده و اميد به زندگى و همرجنين و ماتريس همبستكى بين متغيرهاى

$$
\text { يزوهش را نشان مىدهد. }
$$

نتايج جدول | نشان مىدهد كه بين نكرش مذهبى و مثبت گرايى با اميد به زندگى و همهنين متغيرهاى بين متغيرهاى ميانجى سرسختى روانشناختى و استرس ادراى شده با اميد به زندگى رابطه معنادارى وجود دارد (ه •|•>p).
عدم همخطى جند گانه بين متغيرها است. سطح معنىدارى در آزمونها هـ • • در نظر ترفته شد.

\section{نتايج}

در اين يزوهش • • نفر از بيماران بسترى در بيمارستان

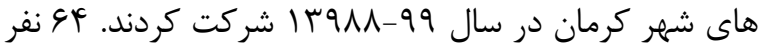

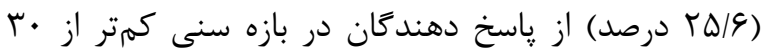

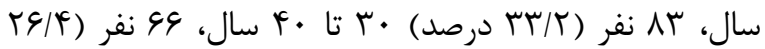

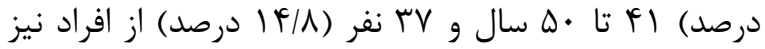

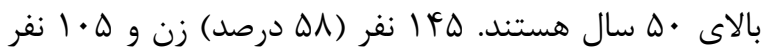

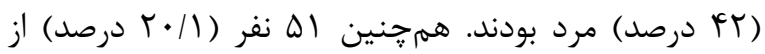

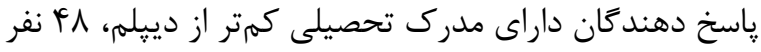

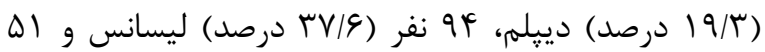

جدول ا - Tمارههاى توصيفى و ماتريس همبسنكى Pearson متغيرهاى يؤوهش

\begin{tabular}{|c|c|c|c|c|c|}
\hline$\Delta$ & f & $r$ & $r$ & 1 & متغيرهاى بيشبين \\
\hline & & & & 1 & ا ا. نكَرش مذهبى \\
\hline & & & 1 & $\cdot|9|^{* *}$ & ז. مثبت كرايى \\
\hline & & 1 & $\cdot / 4 \cdot{ }^{*}$ & $\cdot / F T^{*}$ & r. سرسختى روانشناختى \\
\hline & 1 & $-\cdot / \Delta \mu^{* * *}$ & $-\cdot / 4 \varphi^{*}$ & $-\cdot|r| *$ & F. استرس ادراك شده \\
\hline 1 & $-\cdot|9|^{* *}$ & $-\cdot / 4 q * *$ & $\cdot \mid \Delta V^{* * *}$ & $\cdot 10 \Lambda^{* * *}$ & هـ اميد به زند \\
\hline$T V / V \cdot$ & $r V / \cdot 1$ & $r y / q 1$ & $r q / r \Delta$ & $91 / 99$ & ميانغَين \\
\hline ו ו & $r / \Gamma$. & $r / \uparrow q$ & $r / r \Delta$ & $\uparrow / \mu \wedge$ & انحراف معيار \\
\hline
\end{tabular}

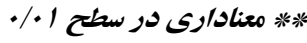

براى اين مدل MF (Comparative fit index; CFI)

شاخص برازش فزآينده (Incremental fit index; IFI) 9 • ، شاخص نيكويى برازش Goodness of fit index; GFI Parsimony ) •94 شاخص برازش هنجار شده مقتصد
جهت تعيين كفايت برازش الكَى پِيشنهادى با دادهها شاخصهاى مذكور مقادير هر يك از اين شاخصها بين ·و ا قرار دارد و مقادير نزديك و يا بيشتر از •9/ • نشانه مطلوب بودن مدل مىباشد [ها]. شاخص برازش مقايسهاى 
حاضر V••• • • له دست آمده است، از طرفى بازه قابل قبول براى آن كمتر از ^••• مىباشد، پس مىتوان كفت مدل برازش شده مدل مناسبى است (شكل Y)، مدل رابطه نكرش مذهبى و مثبت ميانجى گرايانه سرسختى روانشناختى و استرس ادراك شده را نشان مىدهد. با توجه به بارهاى عاملى مدل، تمامى مسيرها تأييد مىشود. (normed fit index; PNFI كه مقدار /VA/• و دامنه قابل قبول آن بزرگتر از • ه/ • مىباشد. شاخصهاى كاى اسكوئر بهنجار شده (Normed chi-square index; CMIN/DF) و شاخص برازش مقايسهاى در دامنه مورد قبول قرار دارد و مدل تدوين شده را مورد حمايت قرار مىدهند. از آنجا كه ريشه دوم ميانگين مربعات خطاى برآورد Root mean) squared error of approximation; RMSEA)

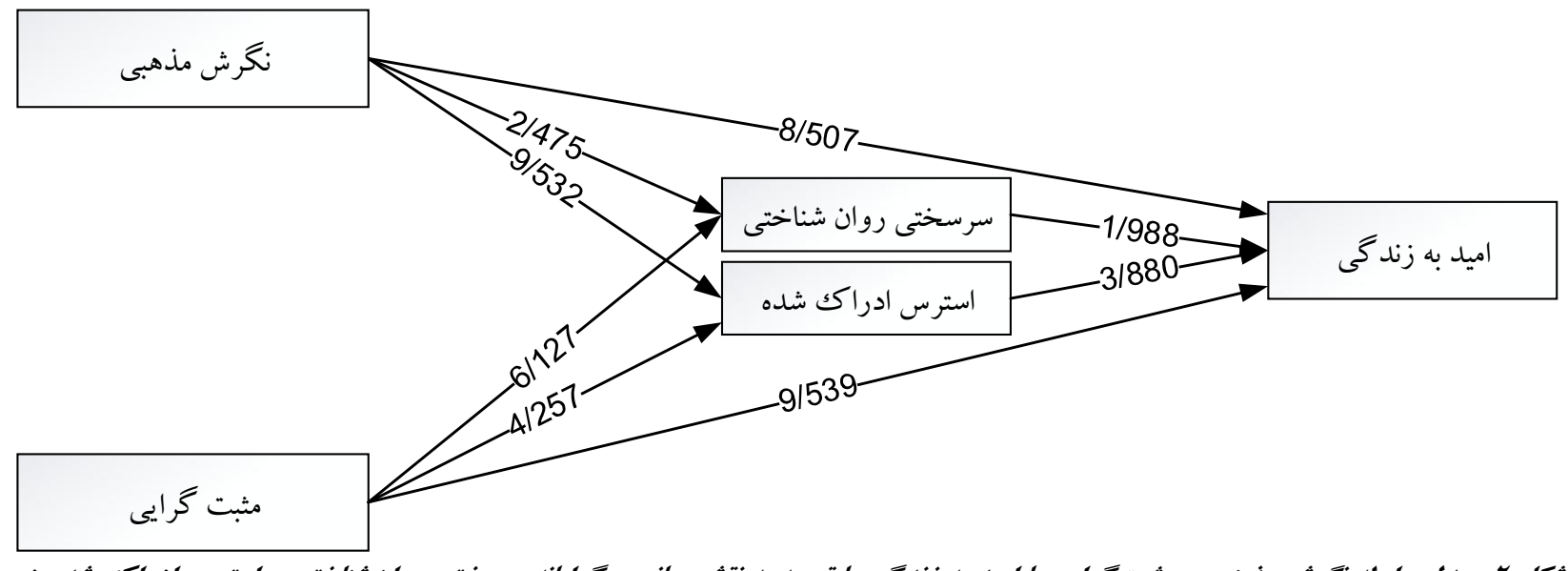

شكل r - ملدل رابطه نترش مذهبى و مثبت مرايع با اميل به زندكى با توجه به نقش ميانجى كرايانه سرسختى روانشناختى و استرس ادراكى شله در

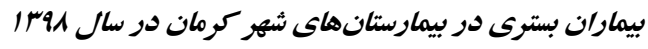

برخوردار هستند. افرادى كه داراى احساسات و باورهاى

مذهبى هستند، نيرويى روزافزون در زندگى آنها وارد مىشود و هنگًامى كه تمام اميدها در نبرد زندگى بر باد مىرود، احساسات و باورهاى مذهبى وارد عمل شده و زندگى تيره و

$$
\text { تار بيماران رادحرَون مىسازد [r]. }
$$

راهكار ايجاد اميد و نشاط در جامعه توجه به نكرش مذهبى و تقويت آن در جامعه مىباشد. ايجاد اميد در مردم جز با تقويت شناخت خداوندى امكانيذير نيست. لذا بايد درصدد باشيم نخرش مذهبى در جامعه حكمفرما شود. در
نتايج تحقيق نشان داد كه بين نكرش مذهبى و اميد به

زندگى رابطه معنىدارى وجود دارد. نتايج يزوهش حاضر با تحقيق Estakhri و همكاران [r] و Chang و Li همخوان بود [ro[ا]. در تبيين اين يافته مىتوان كَت به تعبير قرآن، خسران و بدبختى آنجا است كه آدمى، روح و اميد خود را از دست بدهد زيرا اين امر مىتواند ايمان و اعتقادات دينى او را تحت تأثير قرار دهد. در نتيجه بيماران نسبت به افراد سالم، از آسيبذيرى بيشترى در بعد باورهاى مذهبى 
• • بر رسى ارتباط بين نغرش مذهبى و مثبت گرايى با اميد به زندگى در بيماران بسترى در بيمارستان ...

مى كند تا از عواطف و هيجانهاى مثبت بلمنظور يشت سر

نهادن تجربههاى نامطلوب و بازگَت به وضعيت مطلوب از طريق افزايش سطوح عواطف مثبت و تقويت حرمت خود و

مقابله موفق با تجربههاى منفى استفاده كند [1]].

ابعاد روانشناختى و بعد معنوى بيمار مثل مثبتگرايى و اميد به زندگى در ايسـن قشـر به ارتقاء كيفيت مراقبتها كمك مى كند. براى مقابله با فشار روانى ناشى از بيمارى، نقش مذهب را مىتوان در فرآيند ارزشيابى فشار روانى مدنظر قرار داد. جنان كه اين نقش مذهب در قرآن كريم با اشاره به اين كه مؤمنان به انواع بلايا به عنوان عامـلى جهت امتحــان، رشد و تقويت معنوى مىنگرند قابل استنباط است

تحولات و رويدادهاى استرسزا سلامت افراد را به مخاطره مىاندازد. بيمارى، كنار آمدن با مشكلات و موانع را متأثر مى سازد. در اين بين تمسك به باورهاى مذهبى در ارتقاء سرسختى در برابر موانع مؤثر است. تغيير و تحول، اساساً جنبه مثبتى از زندگى است. لذا افراد سرسخت، تغييرات زندگى را مخاطرهاى براى امنيت تلقى نمى كنند، بلكه اين افراد اعتقاد دارند كه يايدارى در زندگى غيرطبيعى است و بايد انتظار تغييرات را داشت. ضمن اينكه اين تغييرات به عنوان فرضها و مشوقهايى براى رشد و سلامتى نكريسته مىشوند و نه تهديد و بحران [r].

همجنين يافتههاى يزوهش با نتايج تحقيقات Banos و

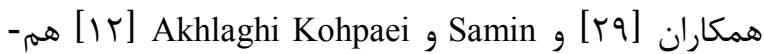
خوانى داشت. در تبيين اين يافته مىتوان اظهار داشت كه اگر بيماران استرس كمترى را ادراك كنند و به اين مههم
واقع اعتقادات مذهبى علاوه بر ريشگيرى از بروز و شيوع بيمارىهاى روانى، مىتواند عوارض جسمانى بيمارىها را كاهش داده و طول مدت بيمارى را كم نمايد و طول عمر را

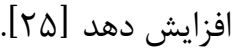
ديخر يافته اين يزوهش نشان داد كه بين مثبترايى و اميد به زندگى بيماران رابطه معنادارى وجود دارد. اين يافته با نتايج تحقيقات Reiter و Ali-Akbari و و

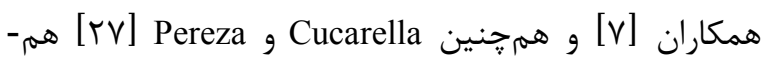
خوان بود. در تبيين اين يافته مىتوان كفت كه مثبتنكرى مىتواند به افراد كمك كند تا روابط موفقترى داشته باشند و در جامعه خود بيشتر درگير شوند، مثبتنگرى باعث احساس خوشبختى و اميدوارى در اوقات سخت دشوار مىشود و مىتواند با افزيش اميدوارى اعتماد به نفس نيز تقويت شود و افراد با اعتماد به نفس بالاترى به سمت موانع و مشكلات مىروند و در مواجهه با مشكلات و موانع سرخورده، افسرده و يا خشمَين نمىشوند [V]. يافته هاى يزوهش نشان داد بين نخرش مذهبى و اميد به زندگى با نقش ميانجى سرسختى روانشناختى بيماران رابطه معنادارى وجود دارد. اين يافته با نتايج تحقيقات Yu و همكاران [ [Y [ و Fouladi و Shahidi [11] همخوانى داشت. در تبيين اين يافته مىتوان كفت كه سرسختى تركيبى از باورهاى فرد درباره خود و روشى است كه به جهان مىنكرد افراد سرسخت با وجود يِيشآمدهاى ناگوار به رويارويى موفق و كار آمد در برابر تنشها اميدوارند، از توانايى يافتن معنى در تجارب آشفته ساز برخوردارند و به نقش خود بهعنوان فرد ارزنده و مهمم باور دارند. سطوح بالاى سرسختى به فرد كمك 
اين امر نخست باعث كاهش ديد منفى به زندگى و افزايش اميد به زندكى و در نهايت باعث افزايش سلامت بيمار مى شوند [•r]. مردم با سرسختى روانشناختى بالا شرايط استرسزا را در مقايسه با افراد با سرسختى روانشناختى ״ايين را بهتر بهكار مىبرند، در حالى كه گروه اول از استراترىهاى مقابله مؤثرترى استفاده مى كنند. سرسختى روانشناختى به نظر مىرسد بهعنوان عاملى اميدواركننده در توسعه سازكارى است. حفظ اميد به زندكى و افزايش آن از مسائل مهم در همه سنين و براى همه اقشار است. اميد علائم و آثار متعددى به جاى مى گذارد. اميد به ما مثبت انديشى، انعطافيذيرى، شور و نشاط و توانيى براى خلاص شدن از ضرباتى كه زندگى بر ما تحميل مى كند را مىدهد و رضايت از زندگى و سلامت روانى و جسمى را افزايش مى-

دهد [11]

يافتهاى يزوهش نشان داد كه بين مثبت زندكى با نقش ميانجى استرس درك شده بيماران رابطه معنادارى وجود دارد. اين يافته با نتايج تحقيقات Lee و همكاران [ [اس]، همخوانى داشت. بيماران با جالشها و و ييامدهاى منفى ناشى از استرس مواجه مىباشند. تأثير موقعيتهاى تنشزا بر سلامت روان وابسته به عواملى مانند نحوه سازگارى با استرس درى شده و نكرش مذهبى به عنوان يكى از جنبههاى مههم حمايتى در بيماران مطرح شده است. افراد مثبتنكر تمايل به تعهد و درگيرى كامل در فعاليتهاى روزمره خود دارند، آنها از خالشها لذت مىبرند و معتقدند كه تغيير و بيمارى امرى طبيعى و قابل قبول است. از اينرو به مشكلات زندگى و بيمارىها به عنوان
اعتقاد راسخ داشته باشند كه آينده مىتواند بهتر باشد، احساس اميد و هدفمندى در آنها افزايش مىيابد و بيماران به اين باور مىرسند كه مىتوانند زندگى و آينده خود را كنترل كنند و موانع احتمالى نمىتواند آنها را متوقف سازد. از سويى ديكر، بيمارانى كه اميد به آينده در آنها وجود دارد داراى باور مثبتى نسبت به توانايىهاى خودشان مقابله با بيمارى و رسيدن به اهدافشان هستند. بنابراين در برابر مشكلات و تنشهاى موجود در زندگى

مقاومت و بردبارى بيشترى از خود نشان مى دهند [1 I ] تقويت باورهاى دينى و معنوى مىتواند با تغيير در شناخت بيمار به طرز شَفت انكَيزى مؤثر واقع شود. بيمارانى كه راهبردهاى سازگارانه مانند بخشش، دوستى با افراد مذهبى، ارتباط معنوى با خدا و اعتقاد به اين كه خدا فقط خير مىرساند را باور دارند و به كار مى گيرند، سريعتر بهبود يافته و سلامت روانى بهترى دارند. اعتقادات دينى افراد را به سوى سازگارى دينى در موقعيتهاى استرسزا رهبرى مى كند و در نتيجه به اميد به زندگى بالاترى را

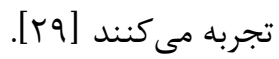
يافتهاى يزوهش نشان داد كه بين مثبت گرايى و اميد به زندگى با نقش ميانجى سرسختى روانشناخى بيماران رابطه Bekelman معنادارى وجود دارد. اين يافته با نتايج تحقيقات و همكاران [•r]، همسو بود. در تبيين اين يافته مىتوان كفت كه افراد سرسخت قدرت كنترل بيشترى بر وقايع زندگى دارند و به جاى دورى از مشكلات آنها را به عنوان فرصت پيشرفت ارزيابى مى كنند. همرجنين آنان رويدادهاى تنيدگىزا را مثبتتر و قابل كنترل تر ارزيابى مى كنند كه 
كس بررسى ارتباط بين نغرش مذهبى و مثبت گرايى با اميد به زندگى در بيماران بسترى در بيمارستان ...

صورت برنامه آموزشى در مراكز درمانى جهت افزايش اميد به زندگى در بيماران توجه شود. همجنين پِيشنهاد مىشود دورههاى آموزشى براى كادر درمانى به منظور افزايش مهارتهاى حرفهاى و لازم جهت تقويت انخيزه اميد به زندگى در بيماران در نظر گرفته شود.

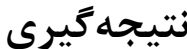

نتايج نشان داد كه تمامى متغيرها (سرسختى روان شناختى، نخرش مذهبى، مثبت گرايى و استرس ادراى شده) توانستند اميد به زندگى را به صورت مستقيم ريشبينى كنند. همرجنين سرسختى روانشناختى و استرس ادراك شده در ارتباط بين نكرش مذهبى، مثبت ترايى و

$$
\begin{aligned}
& \text { اميد به زندگى نقش ميانجى داشتند. } \\
& \text { تشكر و قدردانى }
\end{aligned}
$$

اين مقاله بركرفته شده از پايان نامه دكتراى نويسنده اول است.

بدينويسله از معاونت محترم يزوهشى دانشكاه آزاد اسلامى زرند

جهت ارائه مجوز انجام يزوهش و همهنين كليه بيماران بسترى در بيمارستانهاى شهر كرمان شركت كننده در اين يزوهش،

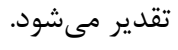

فرصتى براى افزايش مهارتها و توانايىها مىنكرند. سرسختى و مثبتنكرى از منابع درون فردىاند كه مىتوانند سطوح ناتوانى و بيمارى را در شرايط ناگوار تعديل كنند و اثرات منفى فشار و استرس حاصل را كمرنگ جلوه دهند مطالعه حاضر مانند ساير يزوهشهاى حوزه علوم رفتارى و روانشناسى داراى برخى محدوديتها بود. از محدوديتهاى يزوهش حاضر اين بود كه از ابزارهاى خودَزارشى استفاده شده است و اين احتمال وجود دارد كه يرسشنامهها با دقت ياسخ داده نشده باشد. محدود بودن جامعه آمارى به بيماران و همجنين عدم بررسى برخى متغيرهاى مداخلهكر مانند وضعيت اقتصادى، اجتماعى، فرهنكى و خانوادىى تعميميذيرى يافتههاى فوق را با محدوديت روبهرو مىكند. همجنين پيشنهاد مىشود به ״يشينه مذهبى فرد با تأكيد بر بعد معنوى به عنوان مركز ثقل همه ابعاد انسانى در فرآيند درمان بيماران و به خصوص به همراه خانواده درمانى توجه شود. پيشنههاد مىشود در مطالعات آتى به نقش متغير روانشناختى براى بيماران به

\section{References}

[1] Rahimi S, Hajloo N, Basharpoor S. The Prediction of Psychological Well-Being among Students of Mohaghegh Ardebili University in 2018 Based on the Perspective of Time Dimensions (The Mediator Role of Life Expectancy): A Descriptive Study. $J$ Rafsanjan Univ Med Sci 2019; 18 (7): 657-67. [Farsi] 
[2] Estakhri Z, Tajikzadeh F, Kazemi SA. Comparison of the Role of Religious Beliefs in Hopefulness andQuality of Life among Cancer and Non-cancer Patients in Shiraz, Iran. JRH 2016; 4(2): 1-11. [Farsi]

[3] Akbari B. The religious attitude within psychological hardiness attachment styles among students who appeal for divorce. JHNM 2016; 26 (2): 1-8. [Farsi]

[4] Ofstedal MB, Chiu CT, Jagger C, Saito Y, Zimmer Z. Religion, life expectancy, and disability-free life expectancy among older women and men in the United States. The Journals of Gerontology 2019; 74(8): 107-18.

[5] Ganji M, Ganji H. Atkinson and Hilgard Psychology. Tehran: Savalan Press. 2018; 54. [Farsi]

[6] Saeidi Z, Birashk B. Investigating the Effectiveness of Positivism Group Psychotherapy in Life Expectancy and Psychological Well-Being of Cancer Patients. IJSBA 2019; 44(2): 94-110.

[7] Ali-Akbari A, Jajarmi M, Motlagh MG. The Effectiveness of Positivist Psychotherapy Training on the Hope and Psychological Well-being of the Spouses of Imposed War Veterans. JNE 2020; 9(4): 22-30. [Farsi]
[8] Zerach G, Karstoft K, Solomon Z. Hardiness and sensation seeking as potential predictors of former prisoners of wars' posttraumatic stress symptoms trajectories over a 17-year period. JAD 2017; 218 : 176-81. [Farsi]

[9] Salim J, Wadey R, Diss C. Examining the relationship between hardiness and perceived stress-related growth in a sport injury context. JSEP 2015; 19(3): 10-7.

[10] Niroomandi R, Akbari M, Ahmadian H, Bakhshipoor Roodsari A. The Mediating Role of Resilience in the Relationship between Mindfulness and Subjective Well-Being of Diabetic Patients in Bonab County in 2018: A Descriptive Study. J Rafsanjan Univ Med Sci 2020; 19(8): 773-90. [Farsi]

[11] Fouladi N, Shahidi E. The Role of Personality Traits and Life Expectancy in Predicting Psychological Hardiness in Students Regarding Sexuality. CPAP 2020; 15(1): 93-101. [Farsi]

[12] Samin T, Akhlaghi Kohpaei H. Prediction of Life Expectancy based on Quality of Life, Perceived Stress and Fatigue in Patients with Multiple Sclerosis (MS). JHP 2019; 8(1): 108-18. [Farsi]

[13] Asghari F, Ghasemi Jobneh R, Yousefi N, Saadat S, Rafiei Gazani F. Role of perceived stress and coping 
styles on the eating disorders of high school students of Rasht city in 2013. JCHR 2014; 2: 28-38. [Farsi]

[14] McKay MT, Andretta JR, Padgett NR, Cole J. Stress and subjective life expectancy: Cross-sectional and longitudinal associations in early adolescence. IJP 2020; 55 (6): 901-6.

[15] Hooman H. Structural equation modeling using LISREL software. Tehran: Samat Press. 2005. 24. [Farsi]

[16] Golriz G. Study of relationship between religious attitude with other feed back and job characterizations. B.Sc thesis in psychology, faculty of literature and human sciences, Tehran University 1974. 52. [Farsi]

[17] Sadeghi MR. Study of mental health among students of Mazandaran University of Medical Sciences. Abstract proceeding in National Congress of challenges and health improving approaches 2007. [Farsi]

[18] Snyder CR, Harris C, Anderson JR, Holleran SA, Lerving LM, Sigmon ST, et al. The will and the ways: devoleoment and validation of an individualdifferences measure of hope. Meaning in life. Handbook of positive psychology. Oxford. 1991; 24 (6): 747-62.
[19] Ramazani F, hejazi M. The Role of Resilience and Hardiness in Mental Health in Sample of Athlete and Non-Athlete. CPAP 2018; 15(2): 27-36. [Farsi]

[20] Karami Moghadam P, Entesar Fomani G, Hejazi M. Predicting academic self-efficacy based on attributional style and hardiness with the Meditation of academic self-concept in second grade students in Kangawer. EDC 2018; 9: 64-77. [Farsi]

[21] Cohen S, Kamarck T, Mermelstein R. A global measure of perceived stress. JHSB 1983; 24: 385-96.

[22] Safaei M, Shokri O. Assessing Stress in Cancer Patients: Factorial Validity of the Perceived Stress Scale in Iran. INA 2014; 2(1): 13-22. [Farsi]

[23] Scheier MF, Carver CS. Optimism, coping, and health: Assessment and implications of generalized outcome expectancies. J Health Psychol 1985; 4(3): 219-47.

[24] Khodabakhshi-Koolaee A, Entekhabi F, Falsafinejad MR, Sanagoo A. Relationship between optimism and humor with resilience in female nurses of hospitals in Isfahan, Iran. J Gorgan Univ Med Sci 2019; 21(1): 87-93. [Farsi]

[25] Chang L, Li IC. The correlation between perceptions of control and hope status in home-based cancer patients. J Nurs Res 2012; 10(1): 73-82. 
[26] Reiter Ch, Wilz G. Resource diary: A positive writing intervention for promoting well-being and preventing depression in adolescence. J Posit Psychol 2015; 11(1): 99-108.

[27] Cucarella SP, Pereza MC. Positive psychology in women with breast cancer. EpSBS 2015; 1315-30.

[28] Yu KS, Lee HO, Fitzpatrick JJ, Kim S, Marui E, Lee JS, et al. Spirituality, Depression, Living Alone, and Perceived Health Among Korean Older Adults in the Community. Arch Psychiatr Nurs 2014; 23: 309-22.

[29] Banos RM, Etchemendy E, Farfallini L, Palaciosbd AG, Querobd S, Botella C. Earth of well-being system: A pilot study of an information and communication technology-based positive psychology intervention. J Posit Psychol 2014; 9(6): 482-8.

[30] Bekelman DB, Parry C, Curlin FA, Yamashita TE, Fairclough DL, Wamboldt FS. A Comparison of Two Spirituality Instruments and Their Relationship to Depression and Quality of Life in Chronic Heart Failure. JPSM 2010; 39: 515-26.

[31] Lee V, Cohen SR, Edgar L, Laizner AM, Gagnon AJ. Meaning-making intervention during breast or colorectal cancer treatment improves self-esteem, optimism, and self-efficacy. SOC SCI MED 2015; 62(12): 3133-45. 
ع بررسى ارتباط بين نكرش مذهبى و مثبت گرايى با اميد به زندگى در بيماران بسترى در بيمارستان ...

\title{
Investigating the Relationship between Religious Attitude and Positivism and Life Expectancy in Patients Hospitalized in Kerman Hospitals in 2019: The Mediating Role of Psychological Hardiness and Perceived Stress: A Descriptive Study
}

\author{
A. R. Hakimi ${ }^{1}, \underline{\text { F. Khosropour }}{ }^{2}$, S. Khojasteh Chatroudi ${ }^{3}$ \\ Received:22/12/20 Sent for Revision: 08/02/21 Received Revised Manuscript:06/03/21 Accepted:08/03/21
}

Background and Objectives: Belief in God and hope play an important role in continuing the life of all members of society, especially the sick ones. The aim of this study was to investigate the relationship between religious attitude and positivism and life expectancy due to the mediating role of psychological hardiness and perceived stress in patients in hospitals in Kerman.

Materials and Methods: The research method was descriptive and structural equation modeling. The study population was all patients in Kerman hospitals in 2019-2020, out of which 250 people were selected by random multi-stage cluster sampling. The research instruments included Schneider et al.'s Life Examination Questionnaire, Golriz and Baraheni’s Religious Attitude Questionnaire, Ahvaz Psychological Hardiness Questionnaire, Cohen et al.'s Perceived Stress Scale, and Scheier and Carver's Life-orientation Test. Data were analyzed using structural equation modeling.

Results: Mean and standard deviation of religious attitude variables $61.99 \pm 4.38$, life expectancy $27.70 \pm 3.31$, psychological hardiness $34.91 \pm 3.49$, perceived stress $37.01 \pm 3.30$ and positivism was $29.25 \pm 3.35$. The results showed that there was a significant relationship between research variables and the model had a good fit with the data and all coefficients were significant so that psychological toughness and perceived stress had a significant mediating role among religious attitudes, positivism and life expectancy $(\mathrm{p}<0.001)$.

Conclusion: Positivism and religious attitude can predict life expectancy positively and meaningfully, both directly and through the medium of life expectancy. It seems that paying attention to the presented model will be useful in the treatment program and counseling of patients.

Key words: Perceived stress, Life expectancy, Psychological hardiness, Positivism, Religious attitude

Funding: This study did not have any funds.

Conflict of interest: None declared.

How to cite this article: Hakimi A R, Khosropour F, Khojasteh Chatroudi S. Investigating the Relationship Between Religious Attitude and Positivism and Life Expectancy in Patients Hospitalized in Kerman Hospitals in 2019: The Mediating Role of Psychological Hardiness and Perceived Stress: A Descriptive Study. J Rafsanjan Univ Med Sci 2021; 20 (1): 23-36. [Farsi]

1- PhD Student of General Psychology, Dept. of Psychology, Islamic Azad University, Zarand Branch, Zarand, Iran ORCID: 0000000123475061

2- Assistant Prof., Dept. of Psychology, Islamic Azad University, Zarand Branch, Zarand, Iran, ORCID: 00000001225413586

(Corresponding Author) Tel: (034) 32221431, Fax: (034) 32221431, E-mail: Farshid2002@yahoo.com

3- Assistant Prof., Dept. of Psychology, Payame Noor University, Kerman Branch, Kerman, Iran, ORCID: 0000000203547862

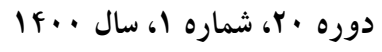

مجله دانشگاه علوم يزشكى رفسنجان 